\title{
United Kingdom Copyright Decisions 2017
}

\author{
Yin Harn Lee
}

Published online: 21 February 2018

(C) The Author(s) 2018. This article is an open access publication

\begin{abstract}
This report highlights the main UK copyright decisions in 2017, which relate to the copyright protection of dramatic formats, the subsistence of copyright and sui generis database right in a database, joint authorship, blocking injunctions, and the sentencing in the context of copyright-related offences.
\end{abstract}

Keywords Authorship - Blocking orders - Communication to the public . Copyright $\cdot$ Database right $\cdot$ Dramatic works $\cdot$ Sentencing

Legislation Copyright, Designs and Patents Act 1988 (UK); European Database Directive 96/9/EC; European Enforcement Directive 2004/48/EC.

Cases Banner Universal Motion Pictures Ltd v. Endemol Shine Group Ltd [2017] EWHC 2600 (Ch); Cartier International AG v. British Sky Broadcasting Ltd [2014] EWHC 3354 (Ch); [2016] EWCA Civ 658; Fixtures Marketing Ltd v. Organismos Prognostikon Agonon Podosfairou C-444/12; Football Association Premier League Ltd v. British Communications plc [2017] EWHC 480 (Ch); Football Association Premier League Ltd v. British Sky Broadcasting Ltd [2013] EWHC 2058 (Ch); Football Dataco Ltd v. Brittens Pools Ltd [2010] EWHC 841 (Ch); Football Dataco Ltd v. Sportradar GmbH [2013] EWCA Civ 27; Green v. Broadcasting Corporation of New Zealand [1989] RPC 700; GS Media BV v. Sanoma Media Netherlands BV C-160/15; Infopaq International A/S v. Danske Dagblades Forening C-5/08; ITV Broadcasting Ltd v. TV Catchup Ltd C-607/11; Martin v. Kogan [2017] EWHC 2927 (IPEC); Nova Productions Ltd v. Mazooma Games Ltd [2006] EWHC 24 (Ch); R v. Evans [2017] EWCA Crim 139; SAS Institute Inc v. World Programming Ltd [2013] EWHC 69 (Ch); Scarlet Extended SA v. Société Belge des Auteurs, Compositeurs et Éditeurs SCRL ("SABAM") C-70/10; Stichting BREIN v. Ziggo BV C-610/15; Svensson v. Retriever Sverige AB C-466/12;

Y. H. Lee (ه)

School of Law, University of Sheffield, Sheffield, UK e-mail: yin.lee@sheffield.ac.uk 
Technomed Ltd v. Bluecrest Health Screening Ltd [2017] EWHC 2142 (Ch); Ukulele Orchestra of Great Britain v. Erwin Clausen \& Yellow Promotion GmbH \& Co Kg (t/a the United Kingdom Ukulele Orchestra) [2015] EWHC 1772 (IPEC); UPC Telekabel Wien GmbH v. Constantin Film Verleih GmbH C-314/12.

\section{Dramatic Formats}

2017 was once again a year of fairly routine copyright jurisprudence from the UK courts, though there were a number of decisions that shed further light on several ongoing debates within copyright law. A case in point is Banner Universal Motion Pictures Ltd v. Endemol Shine Group Ltd, ${ }^{1}$ where the High Court came closer than any UK court had previously done to recognising the subsistence of copyright in the dramatic format of a television programme. In Green v. Broadcasting Corporation of New Zealand, ${ }^{2}$ the first case in which the issue was raised, the Privy Council had denied copyright protection to the format of a talent show, on the ground that the features said to make up the format lacked "sufficient unity" to be capable of performance. The requirement of "sufficient unity" was subsequently held to denote a certain degree of repeatability from performance to performance. ${ }^{3}$ The question of copyright in a dramatic format was raised more recently in Ukulele Orchestra of Great Britain v. Erwin Clausen \& Yellow Promotion $\mathrm{GmbH} \& \mathrm{Co} \mathrm{Kg}$ (t/a the United Kingdom Ukulele Orchestra). ${ }^{4}$ In that case, while HH Judge Hacon did not dismiss the possibility that copyright might subsist in a dramatic format, no such copyright was found on the facts, as the wide range of possible alternative performances meant that the claimed work lacked unity. In Banner Universal Motion Pictures, Snowden J laid down two minimum requirements that must be met for copyright to subsist in a dramatic format: (i) there must be a number of clearly identified features that, taken together, distinguish the format in question from others of a similar type; and (ii) those distinguishing features must be connected with each other in a coherent framework which can be repeatedly applied so as to enable the format to be reproduced in recognisable form. Again, on the facts of the case, no copyright was held to subsist in the claimant's format, which was found to be both unclear and lacking in specifics as well as distinguishing features. However, the judgment of Snowden J does provide future claimants with a much clearer idea of how the requirement of "sufficient unity" might be fulfilled than has hitherto been the case.

\section{Databases}

The case of Technomed Ltd v. Bluecrest Health Screening Ltd, ${ }^{5}$ meanwhile, raised questions relating to the subsistence of copyright and the sui generis database right

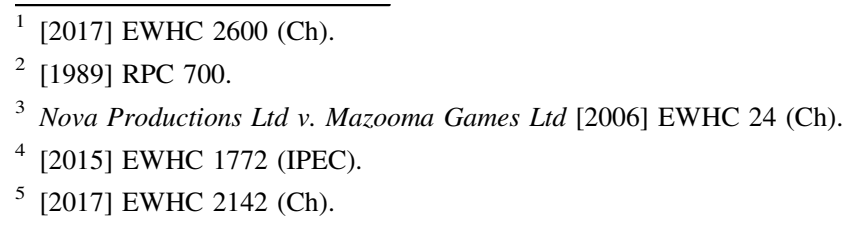


in the context of an electrocardiogram ("ECG") analysis and reporting system known as ECG Cloud. David Stone (sitting as a Deputy High Court Judge) began by holding that the database underlying ECG Cloud was a database within the meaning of the Database Directive and the Copyright, Designs and Patents Act 1988 ("CDPA"), as it constituted "a collection of independent works, data or other materials arranged in a systematic or methodical way and individually accessible by electronic or other means". ${ }^{6}$ In particular, he noted that individual data stored in the database were accessible either by reading the database in the form of a PDF or accessing it as an electronic spread sheet. He also agreed with counsel for the claimants that the claimants had invested substantially in the obtaining, verification and presentation of the contents of the database, ${ }^{7}$ and had particular regard to the fact that the database featured a feedback tool that enabled cardiologists to review and edit various aspects of the relevant data. In doing so, he rejected the submission of counsel for the defendants that there had to be investment directed at preventing the extraction or re-utilisation of the contents of the database, holding that there was no basis for this requirement in the applicable legislation or case law. For these reasons, sui generis database right was held to subsist in the claimants' database, and the defendants' repeated and systematic extraction of the database contents for the purpose of producing patient reports was held to be an infringement of the database right.

On the issue of whether copyright also subsisted in the claimants' database, the judge referred to both the traditional "labour, skill and judgment" test of originality under UK law and the test of "author's own intellectual creation" set out in Infopaq International $A / S$ v. Danske Dagblades Forening. ${ }^{8} \mathrm{He}$ described Infopaq as imposing a "low hurdle", but ultimately concluded that there was no need for him to resolve any debate as to whether the Infopaq test was different to or higher than the test of "labour, skill and judgment", as the claimants' database satisfied both tests. In arriving at this conclusion, he applied the four-step test for database copyright set out in Football Dataco Ltd v. Britten Pools Ltd, ${ }^{9}$ which requires the judicial decision-maker to first isolate those aspects of the database which can properly be regarded as the selection and arrangement of data and then to determine whether the work of selection and arrangement constitutes the author's own intellectual creation. On the facts, it was found that considerable intellectual effort and creativity had been expended in choosing and arranging the contents of the database. This included the selection of the physical characteristics relevant to ECGs, the linking of these characteristics together with options for indicating how they manifested in ECG readings, and the arrangement of these elements in a structured format that would attach to the relevant option a selected risk status indicator and explanatory text aimed at providing further information to patients.

\footnotetext{
${ }^{6}$ Database Directive, Art. 1(2); CDPA, Sec. 3A(1). The court also referred to the cases of Football Dataco Ltd v. Sportradar GmbH [2013] EWCA Civ 27 and Fixtures Marketing Ltd v. Organismos Prognostikon Agonon Podosfairou C-444/02.

7 Database Directive, Art. 7.

8 C-5/08.

9 [2010] EWHC 841.
} 
Another interesting feature of this case is the judge's finding that the format of the data files generated by ECG Cloud was protected by copyright as a literary work. This was something of a departure from the earlier High Court decision of SAS Institute Inc $v$. World Programming Ltd, ${ }^{10}$ where Arnold $\mathrm{J}$ had expressed some doubt as to whether the format of a data file could be regarded as a work. However, as both counsel in Technomed had accepted that the data file format in question could be protected as a literary work provided that it met the originality threshold of "author's own intellectual creation" (which on the facts it was found to do), this aspect of the case was not discussed in much detail.

\section{Authorship}

The issue of authorship was raised in the case of Martin v. Kogan, ${ }^{11}$ which concerned the screenplay on which the film Florence Foster Jenkins was based. The claimant here was identified in the film's credits as the sole author of the screenplay, and he sought a declaration to that effect. The defendant, who had lived with the claimant as his partner during the period in which early drafts of the screenplay were being produced, filed a counterclaim for a declaration that she was the joint author of the screenplay. The defendant contended that she had either written or cowritten a number of scenes in the screenplay, and had provided much of the musical jargon and vocally technical language featured in those scenes.

In his judgment, HH Judge Hacon provided a systematic exposition of the law relating to authorship in the UK, which he summarised as follows: (i) a party will be a joint author of a work only where he or she has collaborated in its creation. The process of collaboration must be by way of a common design, i.e. involving co-operative acts by the authors; (ii) the contribution of each author must not be distinct from those of the other authors; (iii) contributions by a putative joint author which form no part of the creation of the work are to be disregarded; (iv) no distinction is to be drawn between the different types of contribution - such as whether the contribution is textual or non-textual in naturethat do form part of the creation of the work; (v) the contribution must be sufficient, and the question of sufficiency depends on whether the contribution constitutes a substantial part of the work at issue; (vi) if the contribution were copied by an unauthorised third party and such copying would result in an infringement of copyright, the contribution would constitute a substantial part of the work; (vii) the test of substantiality involves a qualitative as well as a quantitative assessment; (viii) suggestions from a putative joint author as to how the main author is to exercise his or her skill will not lead to joint authorship where the main author has the final decision as to the form and content of the work; (ix) it is relevant but not decisive whether an author is the ultimate arbiter as to the content of the work; and (x) if joint authorship is established, the court may apportion ownership of the copyright. On the facts, it was found that the contributions made by the defendant did not rise above the level of providing some useful technical jargon, helpful comments and some minor plot suggestions. These contributions were found to be insufficient to qualify her as a joint author.

\footnotetext{
${ }^{10}$ [2013] EWHC $69(\mathrm{Ch})$.

${ }^{11}$ [2017] EWHC 2927 (IPEC).
} 


\section{Bocking Injunctions}

Football Association Premier League Ltd v. British Communications plc ${ }^{12}$ is the latest case arising from the efforts made by the governing body of the Barclays Premier League ("FAPL") to prevent the unauthorised viewing of Premier League broadcasts through the use of blocking injunctions. ${ }^{13}$ Here, FAPL sought an injunction against the six main retail Internet service providers ("ISPs") in the UK to compel them to block - or at least impede - access by their customers to streaming servers which delivered live streams of Premier League television footage, pursuant to Sec. 97A of the CDPA. This was the first time such order had been sought in relation to streaming servers rather than websites, and was a response to viewers' increasing use of set-top boxes and mobile device apps - which connect directly to streaming servers, rather than to specific websites - to access infringing live streams. Arnold J granted the injunction on the terms sought, which included the following qualifications: (i) the injunction would have effect only at the times when live Premier League match footage was being broadcast; (ii) it would have effect only for a short period of time - i.e. until the end of the current Premier League season - to enable an assessment of its effectiveness; (iii) the list of servers to be blocked would be reset every week, allowing new servers to be identified for blocking by the FAPL but also ensuring that old servers would not continue to be blocked if they were no longer operating as sources of infringing footage; (iv) weekly notices would be sent to hosting providers whose servers were subject to blocking; and (v) hosting providers, operators of websites or streaming services and customers of the defendant ISPs claiming to be affected by the injunction would have permission to apply for it to be varied or set aside.

In arriving at this decision, Arnold $\mathbf{J}$ engaged in the systematic application of the legal principles applicable to blocking injunctions. He began by noting that Sec. 97A of the CDPA empowers the High Court to grant an injunction against a service provider only where that service provider has actual knowledge of another person using their service to infringe copyright. He then found that both the users and the operators of the streaming servers infringed FAPL's copyrights in a number of ways. In relation to users, it was likely that a user who accessed a streaming server would cause a substantial part of a work to be copied in the memory of their computer, mobile device or set-top box, either in a single frame (such as a protected logo) or across a number of frames (such as an "appreciable segment" of a match). The operators of these streaming services, meanwhile, were liable for communicating FAPL's protected works to the public, as they intervened deliberately and in full knowledge of the consequences of their actions to give access to those works in circumstances where the users would not be able to enjoy those works without that intervention. In explaining this aspect of his decision, Arnold J referred to various decisions of the CJEU on the scope of the right to communicate a work to the

\footnotetext{
12 [2017] EWHC 480 (Ch).

13 See also Football Association Premier League Ltd v. British Sky Broadcasting Ltd [2013] EWHC $2058(\mathrm{Ch})$.
} 
public, including ITV Broadcasting Ltd v. TV Catchup Ltd, ${ }^{14}$ Svensson v. Retriever Sverige $A B^{15}$ and GS Media BV v. Sanoma Media Netherlands $B V .^{16}$

Arnold $\mathbf{J}$ then moved on to consider whether the injunction sought was proportionate having regard to the competing fundamental rights of those affected by it, in particular the FAPL's copyrights on the one hand and the defendant ISPs' freedom to carry on business and Internet users' freedom to impart or receive information on the other. ${ }^{17}$ He noted, inter alia, that the injunction would not impair the substance of the defendants' freedom to carry on business, as it would not interfere with the defendants' provision of services to their customers, nor would its implementation require them to acquire new technology. ${ }^{18}$ There was also no suggestion that the implementation of the injunction would be unduly complicated or costly. ${ }^{19}$ Internet users' freedom to impart and receive information would also not be significantly affected, as the servers were dedicated almost exclusively to the provision of infringing streams. To the extent that they might be used for the streaming of lawful content, such content was likely to be very small, and in any event, interference with any legitimate content would only be temporary due to the very short duration of each instance of blocking. Arnold J also agreed with FAPL's contention that the injunction would be effective and dissuasive ${ }^{20}$ in reducing the infringement of FAPL's copyrights, for, inter alia, the following reasons: (i) there was evidence to suggest that the blocking of websites would result in a material reduction in the number of users accessing them; (ii) the blocking of access to streaming servers was likely to be more effective than the blocking of websites which embedded or linked to streams from such servers; (iii) monitoring and blocking techniques had improved considerably since the earlier blocking injunction cases; (iv) there was reason to hope that blocking access to the streaming servers would help educate viewers that infringing streams were not a lawful or reliable way to access Premier League match footage; and (v) despite the prospect that some users or operators might circumvent any blocking put into place, there was no evidence to suggest that the likelihood of this would be higher in the present case than in previous cases. Arnold J also took the view that the availability of other substitute streaming servers did not detract from the effectiveness of the injunction, citing the opinion of Advocate General Szpunar in Stichting BREIN v. Ziggo $B V^{21}$ and both the first instance and appellate decisions in Cartier International AG v. British Sky Broadcasting Ltd. ${ }^{22}$ On this basis, the injunction sought was held to be proportionate.

\footnotetext{
14 C-607/11; IIC 44(6):725 (2013).

15 C-466/12; IIC 45(4):466 (2014).

16 C-160/15; IIC 48(3):342 (2017), https://doi.org/10.1007/s40319-017-0575-0.

17 See Scarlet Extended SA v. Société Belge des Auteurs, Compositeurs et Éditeurs SCRL ("SABAM") C-70/10; UPC Telekabel Wien GmbH v. Constantin Film Verleih GmbH C-314/12.

18 This was reinforced by the fact that five out of the six defendant ISPs positively supported the granting of the injunction.

19 See Enforcement Directive, Art 3(1).

20 See Enforcement Directive, Art. 3(2).

21 C-610/15; IIC 48(6):731 (2017); https://doi.org/10.1007/s40319-017-0628-4.

22 [2014] EWHC 3354 (Ch); [2016] EWCA Civ 658.
} 


\section{Sentencing}

Finally, the case of $R v$. Evans ${ }^{23}$ lays down a number of guidelines to be followed in the sentencing of offenders in relation to copyright-related offences. The appellant here was the administrator of several websites which facilitated access to infringing material on the Internet by directing users to torrent websites. He pleaded guilty to, inter alia, the offence of distributing an article infringing copyright pursuant to Sec. 107(1)(e) of the CDPA, and was sentenced to 12 months' imprisonment. He appealed against the sentence on the ground that it was excessive, contending that it failed to give sufficient weight to the fact that he had not been motivated by financial gain, that he had mental health issues, and that he was of previous good character and unlikely to reoffend. The Court of Appeal upheld his conviction, and in doing so laid down the following guidelines relating to sentencing in such cases: (i) as unlawful downloading and distribution is very often difficult to detect and investigate, deterrent sentencing is appropriate in such cases; (ii) the length of time for which the unlawful activity is carried out is highly relevant; (iii) the profit accruing to the defendant is always relevant; (iv) the loss accruing to copyright owners and the wider impact upon the creative industries is also relevant, even though it may be difficult to quantify in financial terms; (v) in some cases, it may be helpful for the judge to have regard to the Definitive Guidelines issued by the Sentencing Council on offences relating to fraud, bribery and money laundering; (vi) personal mitigation, assistance to the authorities and pleas of guilt are to be taken into account in the usual way; and (vii) unless the unlawful activity is very amateur, minor or short-lived, an immediate custodial sentence is likely to be appropriate in the absence of compelling mitigation or other exceptional circumstances.

Open Access This article is distributed under the terms of the Creative Commons Attribution 4.0 International License (http://creativecommons.org/licenses/by/4.0/), which permits unrestricted use, distribution, and reproduction in any medium, provided you give appropriate credit to the original author(s) and the source, provide a link to the Creative Commons license, and indicate if changes were made.

${ }^{23}$ [2017] EWCA Crim 139. 